\title{
WNIOSEK O ODWOEANIE STAROSTY W ŚWIETLE USTAWY Z DNIA 5 CZERWCA 1998 R. O SAMORZĄDZIE POWIATOWYM
}

\section{WPROWADZENIE}

Ustawa z dnia 5 czerwca 1998 r. o samorządzie powiatowym ${ }^{1}$ (dalej: u.s.p.) stanowi, że: „Rada powiatu może odwołać starostę z innej przyczyny niż nieudzielenie absolutorium lub nieudzielenie wotum zaufania zarządowi jedynie na wniosek co najmniej 1/4 ustawowego składu rady" (art. 31 ust. 1). Tryb odwołania uregulowany został w art. 31 ust. 1-3 u.s.p. ${ }^{2}$ Ustawa określa organ właściwy do odwołania starosty - rada powiatu, warunki formalne wniosku o odwołanie, tryb jego rozpoznania oraz skutki podjęcia uchwały o odwołaniu. $Z$ art. 31 ust. 1 i 3 u.s.p. w zestawieniu $z$ art. 31 a ust. 1 u.s.p. wynika, że odwołanie starosty jest wyrazem woli rady powiatu, wyrażanej w drodze uchwały, i następuje niezależnie od woli samego starosty. Dobrowolne wyrażenie woli zaprzestania pełnienia funkcji starosty przybiera postać rezygnacji, co wyraźnie wynika z art. 31a ust. 1 u.s.p. Dla trybu, o którym mowa w art. 31 ust. 1-4 u.s.p., wola starosty dalszego pełnienia funkcji nie ma decydującego znaczenia, gdyż po złożeniu wniosku o odwołanie to rada powiatu decyduje o dalszym pełnieniu tej funkcji przez daną osobę. Nawet

Dr hab. KATARZYNA KACZMARCZYK-KŁAK, prof. KPSW - kierownik Katedry Prawa Porównawczego i Prawa Pracy, Instytut Prawa i Administracji w Kujawsko-Pomorskiej Szkole Wyższej w Bydgoszczy, ul. Toruńska 55-57, 85-023 Bydgoszcz; sędzia Sądu Apelacyjnego w Rzeszowie; e-mail: kkklak@interia.pl; ORCID: https://orcid.org/0000-0001-6135-7677.

${ }^{1}$ Tekst jedn. Dz.U. z 2020 r., poz. 920.

2 Zob. m.in.: wyrok WSA we Wrocławiu z 30 marca 2016 r., III SA/Wr 86/16, LEX nr 2063628; wyrok WSA we Wrocławiu z 30 marca 2016 r., III SA/Wr 84/16, LEX nr 2063625; wyrok WSA we Wrocławiu z 30 marca 2016 r., III SA/Wr 82/16, LEX nr 2063620. 
złożenie rezygnacji przez starostę nie czyni bezprzedmiotowym przeprowadzenia głosowania w sprawie jego odwołania. W takim bowiem przypadku należy rozpoznać wniosek o odwołanie, albowiem to on został złożony jako pierwszy i uruchomił procedurę, której finałem jest głosowanie uregulowane w art. 31 ust. 3 u.s.p., a ustawa nie przewiduje żadnej możliwości zawieszenia postępowania $\mathrm{w}$ przedmiocie wniosku o odwołanie starosty czy też jego umorzenia. Tym samym złożenie rezygnacji $\mathrm{w}$ trakcie procedury odwołania nie uruchamia postępowania, o którym mowa w art. 31a ust. 2 u.s.p. Jedynie w przypadku śmierci starosty postępowanie w przedmiocie jego odwołania nie jest kontynuowane, nie ma już bowiem kogo odwołać, stało się ono zatem bezprzedmiotowe.

W art. 31 ust. 1 u.s.p. ustawodawca przewidział możliwość dokonania oceny działalności starosty i finalnie - w jej następstwie - jego odwołania. Ocena ta jest niezależna od tej, która zostaje przeprowadzana w ramach postępowania o udzielenie wotum zaufania zarządowi powiatu. Okoliczności, które stanowią podstawę odwołania, nie mogą być tożsame z tymi, które bierze się pod uwagę decydując o udzieleniu wotum zaufania, co wyraźnie wynika $\mathrm{z}$ art. 31 ust. 1 u.s.p.

\section{PRZYCZYNY ZŁOŻENIA WNIOSKU O ODWOŁANIE STAROSTY (PRZYCZYNY ODWOŁANIA STAROSTY)}

W ustawie o samorządzie powiatowym nie wskazano jakichkolwiek szczegółowych przesłanek, które uzasadniałyby podjęcie uchwały o odwołaniu starosty przez radę powiatu, co oznacza, że starosta w zakresie wykonywanych zadań ponosi odpowiedzialność polityczną ${ }^{3}$. Odwołanie może nastąpić „,z innej przyczyny niż nieudzielenie absolutorium lub nieudzielenie wotum zaufania zarządowi”, a więc chodzi tu o każdą „inną przyczynę” niż wskazane powyżej, ustawa posługuje się bowiem pojęciem pojemnym treściowo, a zarazem nieostrym. $Z$ art. 31 ust. 1 u.s.p. wynika, że ustawodawca nie wymienił enumeratywnie, czy też przykładowo, okoliczności uzasadniających odwołanie starosty, jak również nie przyjął w tej materii żadnego rozwiązania kierunkowego (np. posługując się pojęciem „brak możliwości

\footnotetext{
${ }^{3}$ K. Bandarzewski [i in.], Komentarz do art. 31, [w:] K. Bandarzewski, P. Chmielnicki, D. Dąbek, P. Dobosz, W. Kisiel, M. Kotulski, P. Kryczko, M. Mączyński, S. PŁażek, I. SKRZYDŁo-NiżNIK, Komentarz do ustawy o samorzadzie powiatowym, red. P. Chmielnicki, Warszawa: Lexis Nexis 2005, s. 202.
} 
efektywnego wykonywania obowiązków" itp.). Założeniem ustawodawcy jest zatem pozostawienie radzie powiatu samodzielności w ocenie pełnienia funkcji przez starostę, poprzez brak szczegółowych rozwiązań w tym zakresie i tym samym umożliwienie jego odwołania w każdym przypadku, w którym spełnione będą formalne wymogi (art. 31 ust. 1 i 3 u.s.p.), a zdaniem rady powiatu nie będzie właściwe, aby dana osoba nadal pełniła funkcję starosty. Oznacza to, że rada powiatu może kierować się różnymi uwarunkowaniami (okolicznościami), stosując różne kryteria oceny pełnienia funkcji przez starostę, w tym kryteria o charakterze wybitnie uznaniowym ${ }^{4}$.

Podkreślić należy, że z art. 31 ust. 1 u.s.p. wynika, że odwołanie starosty nie musi być związane tylko i wyłącznie z oceną jego dotychczasowej pracy $\mathrm{w}$ charakterze starosty. Taki związek nie wynika bowiem $\mathrm{z}$ tego przepisu. Mowa jest w nim o odwołaniu starosty „z innej przyczyny”, bez określenia jej istoty, charakteru, źródeł, przejawów itp. Może to być zatem przyczyna o charakterze urzędowym, związana z pełnieniem funkcji przez starostę, ale nie musi. „Inną przyczyną” w rozumieniu wskazanego przepisu może być utrata zaufania rady powiatu do starosty, związana z negatywną oceną jego dotychczasowej działalności, choćby nie wynikała ona z zarzutu naruszenia obowiązującego prawa, ale możliwe jest też odwołanie starosty $\mathrm{z}$ tego względu, że jego zachowanie jest negatywnie oceniane przez radę powiatu. Utrata zaufania wynikać może bowiem np. z faktu nagannego zachowania starosty w miejscu publicznym (np. udziału w bójce, prowadzenia pojazdu w stanie nietrzeźwości), nieakceptowanego przez radę powiatu zachowania w życiu prywatnym (np. nieregulowania należności z tytułu obowiązku alimentacyjnego) itp. Oczywiście nic nie stoi na przeszkodzie, aby przyczyną odwołania starosty były nieprawidłowości w zakresie realizacji zadań i obowiązków (w tym niedbalstwo czy też brak staranności) ${ }^{5}$, przy czym nie mogą być to okoliczności oceniane $\mathrm{w}$ ramach postępowania $\mathrm{w}$ przedmiocie udzielenia wotum zaufania, o czym w dalszej części.

Odwołanie starosty w każdym przypadku ma charakter aktu politycznego, związanego z brakiem akceptacji dla dalszego pełnienia funkcji przez starostę ze względu na okoliczności inne, niż będące podstawą nieudzielenia absolutorium lub nieudzielenia wotum zaufania zarządowi, których egzemplifikacja i ocena pozostawiona jest radzie powiatu. Nieudzielenie absolutorium i nieudzielenie wotum zaufania ustawodawca powiązał wyraźnie ze sferą

\footnotetext{
${ }^{4}$ C. MARTysz Komentarz do art. 31, [w:] Ustawa o samorzadzie powiatowym. Komentarz, red. B. Dolnicki, Warszawa: Dom Wydawniczy ABC 2007, teza 1.

${ }^{5}$ K. BANDARZEWSKi [i in.], Komentarz do art. 31, s. 202.
} 
działalności zarządu powiatu (art. 30 ust. 1 u.s.p. i art. 30a ust. 1, 2 i 9 u.s.p.), natomiast $\mathrm{w}$ przypadku instytucji odwołania starosty takiej zależności brak, nie można zatem wykluczyć, że „inną przyczyną” będą okoliczności o charakterze personalnym, odnoszące się do osoby starosty, jego zachowania wobec innych osób (w tym najbliższych), sytuacji rodzinnej, postawy, prezentowanych przez niego ocen i poglądów, w tym także związane $\mathrm{z}$ formułowanymi w przestrzeni publicznej pod jego adresem zarzutami np. o charakterze kryminalnym, korupcyjnym, obyczajowym itp. Ustawodawca nie wyłączył okoliczności osobistych z kręgu tych, które przemawiać mogą - zdaniem rady powiatu - za odwołaniem starosty. Nie można zatem uznać, że rada powiatu nie jest władna odwołać starostę $\mathrm{z}$ tego powodu, że np. negatywnie ocenia prezentowaną przez niego postawę życiową. Co istotne, rada powiatu nie jest zobowiązana do poczynienia we wskazanym zakresie żadnych ustaleń faktycznych, nie musi oczekiwać na wyjaśnienie wskazanych okoliczności we właściwym trybie (np. w ramach postępowania karnego), jej ocena nie przesądza bowiem, że takie czy inne okoliczności zaistniały (miały miejsce). Rada powiatu nie ustala tych okoliczności (nie ma w tym zakresie żadnej kompetencji), nie prowadzi żadnego postępowania $w$ tej materii, a jedynie ocenia, czy dana osoba może pełnić funkcję starosty w obliczu pojawienia się tego typu informacji, czy taka sytuacja jest akceptowana z punktu widzenia prawidłowego funkcjonowania samorządu powiatowego. Odwołanie starosty nie jest równoznaczne $\mathrm{z}$ ustaleniem, że takie okoliczności - zdaniem rady powiatu - miały miejsce. Rada powiatu musi ocenić, czy informacje, które uzyskała, biorąc pod uwagę ich charakter, wiarygodność itp., w jej ocenie negatywnie rzutują na zdolność starosty do dalszego pełnienia swej funkcji.

W świetle art. 31 ust. 1 u.s.p. możliwa jest sytuacja, że obiektywnie rzecz ujmując, starosta prawidłowo będzie wykonywał swoje obowiązki, czyniąc to zgodnie $\mathrm{z}$ prawem i interesem powiatu, ale ocena rady powiatu może być inna i ostatecznie przesądzić o zakończeniu jego misji. Podzielić należy pogląd prezentowany w piśmiennictwie, że dla odwołania starosty wystarczająca jest negatywna ocena jego działań lub zaniechań przez radę powiatu, choćby były one zgodne $\mathrm{z}$ obowiązującym prawem lub wręcz nie były przez prawo regulowane ${ }^{6}$. Wystarczająca jest również negatywna ocena przez radę powiatu innych okoliczności niż te, które związane są z wykonywaniem obowiązków przez starostę, co jest następstwem posłużenia się przez ustawodawcę sformułowaniem „z innych przyczyn”. Okoliczności, które rada powiatu uzna za przemawiające za odwołaniem starosty, obiektywnie mogą nie uzasadniać

\footnotetext{
${ }^{6}$ Tamże.
} 
takiego rozstrzygnięcia, a ponadto ustawa nie wymaga, aby odwołanie starosty było następstwem ich udowodnienia lub uprawdopodobnienia. Zaprezentowane poglądy znajdują pełne umocowanie w art. 31 ust. 1 u.s.p. $Z$ przepisu tego wynika bowiem, że kompetencja do odwołania starosty przysługuje radzie powiatu („Rada powiatu może odwołać starostę...”), która uznaniowo dokonuje oceny, czy zachodzi do tego podstawa (,inna przyczyna niż nieudzielenie absolutorium"), a więc czy jest takie uzasadnienie, decydujące znaczenie ma zatem wola rady powiatu, wyrażająca się w głosowaniu, o którym mowa $\mathrm{w}$ art. 31 ust. 3 u.s.p. Trafne jest $\mathrm{w}$ związku $\mathrm{z}$ tym spostrzeżenie, że wniosek o odwołanie starosty (a więc w istocie rzeczy całego zarządu) można złożyć w każdej sytuacji, o ile w ocenie co najmniej $1 / 4$ ustawowego składu rady zasługuje na rozpatrzenie, zaś o tym, czy jest on zasadny czy też nie, zdecydują radni podczas głosowania w sprawie odwołania starosty ${ }^{7}$.

$\mathrm{Z}$ art. 31 ust. 1 u.s.p. wynika, że podstawą odwołania starosty nie może być negatywna ocena wykonania budżetu. Ocena w tym zakresie następuje w ramach postępowania, o którym mowa w art. 31 ust. 3 u.s.p., dotyczy całego zarządu, a więc także i starosty. Uregulowanie w ustawie o samorządzie powiatowym instytucji odwołania zarządu powiatu z powodu nieudzielenia absolutorium (art. 30 ust. 1 u.s.p.) oznacza, że w tym przypadku procedura ma charakter szczególny, czego z kolei efektem jest brak możliwości podniesienia zarzutów związanych $\mathrm{z}$ wykonaniem budżetu $\mathrm{w}$ postępowaniu w przedmiocie odwołania starosty, uregulowanym art. 31 u.s.p. Co istotne, inne okoliczności niż związane z wykonaniem budżetu nie mogą być podstawą nieudzielenia zarządowi powiatu absolutorium ${ }^{8}$, a w konsekwencji nieudzielenie absolutorium $\mathrm{z}$ innych przyczyn, niż ocena wykonania budżetu stanowi istotne naruszenie art. 12 pkt 6 u.s.p. ${ }^{9}$ Analogicznie, podniesienie zarzutów odnośnie do wykonania budżetu nie jest możliwe we wniosku o odwołanie starosty i okoliczności w tym zakresie nie mogą uzasadniać takiego rozstrzygnięcia.

Art. 31 ust. 1 u.s.p. zmieniony został przez art. 2 pkt 11 ustawy z dnia 11 stycznia 2018 r. ustawy o zmianie niektórych ustaw w celu zwiększenia udziału obywateli $\mathrm{w}$ procesie wybierania, funkcjonowania i kontrolowania

\footnotetext{
${ }^{7}$ C. MARTYSZ, Komentarz do art. 31, teza 1 i 2.

${ }^{8}$ Wyrok NSA z 22 marca 1996 r., SA/Gd 3695/95, LEX nr 79742; uchwała Kolegium Regionalnej Izby Obrachunkowej z 24 lipca 2013 r., 79/2013, LEX nr 1728402.

${ }^{9}$ Zob. wyrok NSA z 14 stycznia 2002 r., I SA/Po 1606/01, „Finanse Komunalne” 2003, nr 2, s. 56.
} 
niektórych organów publicznych ${ }^{10}$ (dalej: ustawa z dnia 11 stycznia 2018 r.), zmieniającej ustawę o samorządzie powiatowym z dniem 31 stycznia $2018 \mathrm{r}$. (art. 19). Zgodnie z art. 15 ustawy z dnia 11 stycznia 2018 r. wprowadzone zmiany stosuje się do kadencji organów jednostek samorządu terytorialnego następujących po kadencji, w czasie której powołana ustawa weszła w życie. W wyniku nowelizacji do wskazanego przepisu wprowadzono sformułowanie: „lub nieudzielenie wotum zaufania”, co oznacza, że przyczyny nieudzielenia wotum zaufania nie mogą być przyczynami uzasadniającymi odwołanie starosty. Ustawa z dnia 11 stycznia 2018 r. dodała do ustawy o samorządzie powiatowym art. 30a, z którego wynika obowiązek przedstawienia przez zarząd powiatu radzie powiatu co roku do dnia 31 maja raportu o stanie powiatu (ust. 1), który obejmuje podsumowanie działalności zarządu powiatu w roku poprzednim, w szczególności realizację polityk, programów i strategii, uchwał rady powiatu i budżetu obywatelskiego (ust. 2). Po zakończeniu debaty nad raportem o stanie powiatu rada powiatu przeprowadza głosowanie nad udzieleniem zarządowi powiatu wotum zaufania. Uchwałę o udzieleniu zarządowi powiatu wotum zaufania rada powiatu podejmuje bezwzględną większością głosów ustawowego składu rady powiatu. Niepodjęcie tej uchwały jest równoznaczne $\mathrm{z}$ podjęciem uchwały o nieudzieleniu zarządowi powiatu wotum zaufania (art. 30a ust. 9). Nieudzielenie przez radę powiatu wotum zaufania zarządowi powiatu jest równoznaczne ze złożeniem wniosku o odwołanie zarządu (art. 30a ust. 10).

Z powyższego wynika, że odwołanie starosty nie może nastąpić $\mathrm{z}$ tej samej przyczyny, co nieudzielenie wotum zaufania na podstawie art. 30a ust. 9 u.s.p. „Inna przyczyna”, o której mowa w art. 31 ust. 1 u.s.p., to zatem każda inna okoliczność, niż podstawa do nieudzielenia wotum zaufania. Pojawia się jednak pytanie, czy to oznacza, że ocena działalności starosty w obecnym stanie prawnym dokonywana jest wyłącznie na podstawie art. 30a ust. 9 u.s.p., czy też możliwa jest ona $\mathrm{w}$ ramach postępowania w przedmiocie jego odwołania?, a jeżeli tak, to w jakim zakresie?

Kluczem do odpowiedzi na powyższe pytanie/pytania jest ustalenie zakresu przedmiotowego raportu o stanie powiatu, z oceną tego dokumentu powiązano bowiem możliwość nieudzielenia wotum zaufania zarządowi powiatu. Ustawodawca przyjął, że raport o stanie powiatu obejmuje „podsumowanie działalności zarządu powiatu”, przykładowo wskazując (,w szczególności”), jakie kwestie (zagadnienia) powinny być w nim ujęte. Art. 30a ust. 2 u.s.p. określa zakres przedmiotowy raportu o stanie powiatu w sposób bardzo

${ }^{10}$ Dz.U. z 2018 r., poz. 130. 
zwięzły, wręcz lakoniczny, tak samo jak art. 28aa ust. 2 ustawy z dnia 8 marca 1990 r. o samorządzie gminnym ${ }^{11}$ (dalej: u.s.g.) ${ }^{12}$. Z całą pewnością w ramach owego „podsumowania” niezbędne jest przedstawienie przez zarząd powiatu sprawozdania z realizacji zadań, o których mowa w art. 32 ust. 1 i 2 u.s.p., jak również z funkcjonowania starostwa powiatowego oraz jednostek organizacyjnych powiatu, zgodnie bowiem z art. 33 u.s.p. zarząd wykonuje zadania powiatu przy pomocy starostwa powiatowego oraz jednostek organizacyjnych powiatu. Raport o stanie powiatu musi także obejmować „podsumowanie" z realizacji zadań przez starostę, bowiem to starosta organizuje pracę zarządu powiatu i starostwa powiatowego, kieruje bieżącymi sprawami powiatu oraz reprezentuje powiat na zewnątrz (art. 34 ust. 1 u.s.p.), jest też kierownikiem starostwa powiatowego oraz zwierzchnikiem służbowym pracowników starostwa i kierowników jednostek organizacyjnych powiatu oraz zwierzchnikiem powiatowych służb, inspekcji i straży (art. 35 ust. 2 u.s.p.). Raport o stanie powiatu dotyczy zatem także działalności starosty, nie ograniczając się przy tym wyłącznie do jego aktywności, jako przewodniczącego zarządu powiatu (art. 26 ust. 2 u.s.p.). Raport ten dotyczy bowiem ,podsumowania działalności zarządu powiatu w roku poprzednim", co oznacza, że obejmuje zarówno działalność zarządu powiatu, jako organu kolegialnego, jak i jego poszczególnych członków, którzy realizują określone zadania, w tym starosty, którego zadania i kompetencje wynikają wprost z ustawy o samorządzie powiatowym. Działalność zarządu powiatu, o której mowa w art. 30a ust. 2 u.s.p., to nie tylko działalność kolegialna, ale także działalność poszczególnych jego członków, ona bowiem składa się na realizację zadań powiatu mieszczących się w pojęciu „działalności zarządu powiatu” w rozumieniu art. 30a ust. 2 u.s.p. W konsekwencji „przyczyny” stanowiące podstawę do nieudzielenia wotum zaufania zarządowi powiatu, o którym mowa w art. 30a ust. 9 i 10 u.s.p., nie mogą stanowić podstawy do odwołania starosty $w$ trybie art. 31 u.s.p. Co istotne, przyjęte rozwiązanie odnosi się do „innej przyczyny niż nieudzielenie wotum zaufania”, a więc podstawy faktyczne uzasadniające nieudzielenie wotum zaufania nie podlegają ocenie $\mathrm{w}$ ramach postępowania w przedmiocie odwołania starosty, o którym mowa w art. 31 ust. 1-4 u.s.p. W tym przypadku ustawodawca przewidział złożoną procedurę, a mianowicie najpierw przeprowadzenie głosowania nad udzieleniem zarządowi powiatu wotum zaufania (art. 30a ust. 9 u.s.p.), w przypadku jego nieudzielenia automatycznie dochodzi do wszczęcia postępowania

\footnotetext{
${ }^{11}$ Tekst jedn. Dz.U. z 2020 r., poz. 713 z późn. zm.

${ }^{12}$ M. KarCiARZ, Raport o stanie jst - istota, zakres, przygotowanie, LEX/el 2018, pkt 3.
} 
w przedmiocie odwołania zarządu (art. 30a ust. 10 u.s.p.), co prowadzić może do odwołania zarządu (art. 30a ust. 11 u.s.p.).

Okoliczności związane z działalnością zarządu powiatu mogą być zatem oceniane wyłącznie $\mathrm{w}$ ramach postępowania $\mathrm{w}$ przedmiocie udzielenia zarządowi wotum zaufania, a następnie - w przypadku nieudzielenia wotum zaufania - w postępowaniu uregulowanym w art. 30a ust. 11 u.s.p. Nie chodzi tu tylko o okoliczności, które były podniesione w ramach tego postępowania, ale o okoliczności stanowiące podstawę oceny działalności zarządu powiatu w ramach raportu o stanie powiatu. Ustawa nie wprowadziła bowiem rozwiązania, że wyłączenie, o którym mowa w art. 31 ust. 1 u.s.p., dotyczy tylko przypadku, w którym określone okoliczności były przedmiotem oceny $w$ ramach procedury zawartej $w$ art. 30a ust. 11 u.s.p. $Z$ art. 31 ust. 1 u.s.p. wynika, że wyłączenie dotyczy „przyczyny” uzasadniającej nieudzielenie wotum zaufania, a więc związanej z oceną działalności zarządu powiatu, co ma charakter obiektywny, odbywając się w ramach zakreślonych przez ustawę. Taka „przyczyna” może być oceniana wyłącznie w postępowaniu wskazanym w art. 30a ust. 11 u.s.p. Udzielenie wotum zaufania wyklucza możliwość przeprowadzenia postępowania w przedmiocie odwołania zarządu powiatu (arg. ex art. 30a ust. 10 u.s.p.), a w konsekwencji eliminuje możliwość skutecznego przeprowadzenia postępowania o odwołanie starosty (arg. ex art. 31 ust. 1 u.s.p.), w ramach tego postępowania nie można bowiem analizować okoliczności związanych z działalnością zarządu powiatu, gdyż ta jest oceniana w szczególnej procedurze, uregulowanej w art. 30a u.s.p., i w tym przepisie uregulowano samodzielną podstawę do przeprowadzenia postępowania w przedmiocie odwołania zarządu powiatu (art. 30a ust. 11 u.s.p.). „Przyczyna nieudzielenia wotum zaufania” w rozumieniu art. 31 ust. 1 u.s.p. to negatywna ocena działalności zarządu powiatu w następstwie analizy raportu o stanie powiatu w zakresie, w jakim ustawa zobowiązuje do podsumowania tej działalności w jego ramach. „Inna przyczyna niż nieudzielenie wotum zaufania" to zatem inna podstawa, niż negatywa ocena działalności zarządu powiatu, w tym starosty, we wskazanym powyżej rozumieniu.

Powyższe uwagi nie oznaczają, że odwołanie starosty, o którym mowa w art. 31 ust. 1-4 u.s.p., nie może nastąpić z powodu negatywnej oceny jego działalności. Odwołanie starosty może być uwarunkowane względami merytorycznymi, art. 31 ust. 1 u.s.p. nie wyklucza bowiem takiej ewentualności. Ze względu jednak na jego brzmienie i treść art. 30a ust. 9-11 u.s.p. wyrazić należy pogląd, że przyczyną odwołania starosty nie mogą być okoliczności, które stanowią (a ściślej: stanowić mogą) podstawę do nieudzielenia wotum 
zaufania zarządowi powiatu i finalnie prowadzą do odwołania zarządu w trybie art. 30a ust. 11 u.s.p. Tym samym przesłankami, które mogą stanowić podstawę złożenia wniosku o odwołanie starosty, są m.in. w szczególności: kultura urzędowania; relacje z podwładnymi; stopień zaangażowania i poświęcenia przy realizacji zadań i obowiązków; umiejętność przewidywania i rozwiązywania sytuacji kryzysowych; formułowane propozycje i plany ich charakter, zakres, realność realizacji; umiejętność pozyskiwania funduszy zewnętrznych; troska o wizerunek samorządu; polityka informacyjna; troska o dobro wspólne (jej przejawy) itp. Wskazane okoliczności połączone są wprawdzie z pełnieniem funkcji przez starostę, ale wykraczają poza działalność zarządu powiatu w rozumieniu art. 30a ust. 2 u.s.p., dotyczą bowiem okoliczności, które związane są ściśle z osobą starosty (a ściślej: z prezentowanym przez niego modelem, stylem i sposobem urzędowania), $z$ jego przygotowaniem do realizacji zadań i obowiązków, umiejętnościami (w tym z zakresu komunikacji społecznej), z jego zdolnościami do efektywnego realizowania zadań, stopniem zaangażowania w pełnienie funkcji, zachowaniem wobec innych osób itp. „Podsumowanie działalności zarządu powiatu”, o którym mowa w art. 30a ust. 2 u.s.p., nie obejmuje ani samooceny poszczególnych osób wchodzących w skład zarządu powiatu, ani też okoliczności odnoszących się m.in. do ich zaangażowania, kwalifikacji i zdolności realizowania powierzonych im zadań i obowiązków. Owe „podsumowanie” to fakty odnoszące się do działań podejmowanych przez zarząd powiatu, m.in. w kontekście realizacji polityk, programów i strategii, i te fakty podlegają ocenie w kontekście udzielenia wotum zaufania. W ramach oceny raportu o stanie powiatu analizuje się zatem to, czy starosta wykonuje swoje obowiązki, czy przestrzega terminów, co ma charakter formalny (jakie obowiązki są realizowane, a jakie nie są, w jakim zakresie obowiązki nie są realizowane, jaka jest tego przyczyna - zależna od danej osoby czy też niezależna, obiektywna itp.), czy ,jest dobrym gospodarzem”, zaangażowanym w sprawy powiatu, poświęcającym sprawom urzędowym maksimum niezbędnego czasu, mając jasną i przemyślaną wizję jego rozwoju, potrafiącym eliminować i rozwiązywać konflikty oraz przekonująco uzasadniać podejmowane decyzje, dbającym o kulturę w miejscu pracy, o właściwą relację na linii starostwo powiatowe i powiatowe jednostki organizacyjne a obywatel. Podsumowując: wszystko to, co wykracza poza „działalność zarządu powiatu" w rozumieniu art. 30a ust. 2 u.s.p., a mieści się w zakresie urzędowania starosty, może być podstawą sformułowania wniosku o jego odwołanie, o którym mowa w art. 31 ust. 1 u.s.p. 


\section{WYMOGI FORMALNE WNIOSKU O ODWOŁANIE STAROSTY}

Wniosek o odwołanie starosty wymaga formy pisemnej (art. 31 ust. 2 in principio u.s.p.). Ustawa wyklucza zatem możliwość jego sformułowania $\mathrm{w}$ innej formie, $\mathrm{w}$ tym w ustnej. Jego elementem jest uzasadnienie, co wynika z tego, że ustawa o samorządzie powiatowym wyraźnie stanowi, że „wniosek... wymaga uzasadnienia przyczyny odwołania" (art. 31 ust. 2 u.s.p.), a to oznacza, że jest ono jego częścią. W konsekwencji również i uzasadnienie przyczyny odwołania przybrać musi - jako element wniosku - formę pisemną. Za powyższą wykładnią dodatkowo przemawia brzmienie art. 31 ust. 5 u.s.p. Przepis ten stanowi, że: „Rada powiatu może na uzasadniony wniosek starosty odwołać poszczególnych członków zarządu zwykłą większością głosów w obecności co najmniej połowy ustawowego składu rady, w głosowaniu tajnym". W tym przypadku ustawa nie wymaga dla wniosku starosty o odwołanie członka zarządu powiatu formy pisemnej, dlatego też może być on zgłoszony ustnie, a w konsekwencji również i uzasadnienie może przybrać taką właśnie formę, co nie budzi wątpliwości w piśmiennictwie ${ }^{13}$. W orzecznictwie trafnie przyjęto, że dopuszczalne jest ustne uzasadnienie wniosku starosty o odwołanie członka zarządu powiatu, a przepisy regulaminowe, jako przepisy aktu niższego rzędu, nie mogą w żaden sposób ograniczać regulacji ustawowej ${ }^{14}$. Podkreślono przy tym, że wystarczające jest ,jakiekolwiek uzasadnienie wspierające wniosek"15. W art. 31 ust. 2 u.s.p. przyjęto wyraźnie inne rozwiązanie niż w art. 31 ust. 5 u.s.p., o charakterze bardziej formalistycznym, określając zarówno formę wniosku, jak i formę uzasadnienia, w obu przypadkach wymagając zachowania formy pisemnej. Art. 31 ust. 5 u.s.p. nie wyklucza złożenia pisemnego wniosku wraz z uzasadnieniem o odwołanie członka zarządu powiatu ${ }^{16}$, ale nie jest to wymóg ustawowy, tak jak to przyjęto w art. 31 ust. 2 u.s.p.

Uzasadnienie wniosku o odwołanie starosty obejmuje uzasadnienie przyczyny odwołania (art. 31 ust. 2 u.s.p.). Wynika z tego, że wniosek taki ma być umotywowany. Należy w nim wskazać przyczynę (przyczyny) przemawiającą (przemawiające) za zasadnością odwołania starosty. Ustawa nie wymaga przy tym, aby okoliczności wskazane w uzasadnieniu wniosku zostały w jakikolwiek sposób udokumentowane. $\mathrm{Z}$ art. 31 ust. 2 u.s.p. nie wynika obowiązek dołączenia do wniosku załączników, potwierdzających wystąpienie okoliczności,

\footnotetext{
${ }^{13}$ C. MARTYSZ, Komentarz do art. 31, teza 4.

${ }^{14}$ Wyrok WSA w Warszawie z 14 listopada 2016 r., II SA/Wa 2177/05, LEX nr 295001.

${ }^{15}$ Wyrok WSA w Rzeszowie z 20 grudnia 2017 r., II SA/Rz 1034/17, LEX nr 2434076.

${ }^{16}$ Zob. wyrok WSA w Rzeszowie z 20 grudnia 2017 r., II SA/Rz 1033/17, LEX nr 2434075.
} 
które stanowią podstawę złożenia wniosku. Nie oznacza to, że wnioskodawcy nie są zobowiązani do wykazania przyczyny uzasadniającej odwołanie starosty. W każdym przypadku wniosek musi zawierać uzasadnienie podstawy odwołania, ale ustawa nie określa tu żadnych formalnych wymogów, w tym nie wymaga, aby twierdzenia wnioskodawców zostały udowodnione lub co najmniej uprawdopodobnione, to zaś oznacza, że do wniosku nie jest niezbędne dołączenie jakichkolwiek dokumentów, opinii, stanowisk itp. Nie ma żadnych przeszkód, aby uzasadnienie wniosku było rozbudowane, a poszczególne okoliczności, które zostały w nim podniesione, wykazane poprzez dołączenie do wniosku o odwołanie stosownych materiałów, ale nie jest to wymóg ustawowy, od którego uzależniona jest skuteczność wniosku o odwołanie. Nawet lakoniczne uzasadnienie przyczyny odwołania spełnia wymóg, o którym mowa w art. 31 ust. 2 u.s.p. Brak dołączenia materiałów, uzasadniających przyczynę odwołania, nie uchybia wskazanemu przepisowi i w związku z tym nie może być kwalifikowany jako uchybienie formalne uniemożliwiające nadania wnioskowi o odwołanie biegu, bo - jak już stwierdzono - ustawa nie wymaga dołączenia niczego do wniosku o odwołanie starosty.

Powyższe stanowisko nie kłóci się z założeniem, że procedura określona w art. 31 u.s.p. ma na celu ograniczenie liczby pochopnych wniosków o odwołanie starosty, m.in. poprzez wymóg uzasadnienia przyczyny odwołania ${ }^{17}$. Owe ograniczenie wynika bowiem z nałożenia obowiązku uzasadnienia przyczyny odwołania, a zatem ustawa wyklucza składanie wniosków nie popartych żadnymi faktami, ale ocena tego, co przedstawili wnioskodawcy, pozostawiona została radnym - to oni oceniają w głosowaniu, czy argumentacja przedstawiona przez wnioskodawców jest wyczerpująca i przekonująca, uzasadniając odwołanie starosty. Podkreślić należy, że ustawa o samorządzie powiatowym nie wymaga, aby uzasadnienie przyczyny odwołania było „należyte” czy też „szczegółowo” wyjaśniało przyczynę (przyczyny) uzasadniającą (uzasadniające) odwołanie ${ }^{18}$.

Wniosek o odwołanie starosty musi pochodzić od co najmniej $1 / 4$ ustawowego składu rady (art. 31 ust. 1 in fine u.s.p.), co oznacza, że taka część rady powiatu musi złożyć podpis pod wnioskiem. Podpisanie wniosku stanowi ustawowy wymóg o charakterze formalnym ${ }^{19}$. Brak wymaganej liczby podpisów oznacza, że wniosek nie został skutecznie złożony i nie może otrzymać

\footnotetext{
${ }^{17}$ Wyrok WSA w Szczecinie z 12 maja 2016 r., II SA/Sz 249/16, LEX nr 2098486

${ }^{18}$ Zob. wyrok WSA w Gliwicach z 8 listopada 2017 r., IV SA/Gl 280/17, LEX nr 2396880.

${ }^{19}$ Zob. wyrok WSA w Szczecinie z 12 maja 2016 r., II SA/Sz 249/16, LEX nr 2098486; postanowienie WSA w Gliwicach z 10 sierpnia 2017 r., IV Sa/Gl 711/17, LEX nr 2345257; wyrok SO w Gorzowie Wielkopolskim z 22 czerwca 2017 r., VI Pa 35/17, LEX nr 2659619.
} 
dalszego biegu. Wymagana liczba podpisów oceniana jest na dzień złożenia wniosku, to bowiem w tej dacie musi on spełniać wszystkie wymogi formalne. Ustawa łączy bowiem z datą jego złożenia określone skutki (art. 31 ust. 3 u.s.p.), jest zatem oczywiste, że tylko wniosek skutecznie złożony może zainicjować postępowanie w przedmiocie odwołania starosty.

\section{ORGAN, DO KTÓREGO KIEROWANY JEST WNIOSEK O ODWOŁANIE STAROSTY}

Adresatem wniosku o odwołanie starosty jest rada powiatu (art. 31 ust. 1 u.s.p.). Wniosek składa się na ręce przewodniczącego rady powiatu. Wprawdzie nie wynika to wyraźnie z ustawy, ale jest konsekwencją rozwiązania przyjętego w art. 15 ust. 1 u.s.p. Zgodnie z tym przepisem: „Rada powiatu obraduje na sesjach zwoływanych przez przewodniczącego rady powiatu w miarę potrzeby, nie rzadziej jednak niż raz na kwartał. Do zawiadomienia o zwołaniu sesji dołącza się porządek obrad wraz z projektami uchwał". Skoro to przewodniczący rady powiatu zwołuje sesje rady powiatu, a ustawa określa tryb rozpoznania wniosku przez radę powiatu (art. 31 ust. 3 u.s.p.), jest oczywiste, że bieg wnioskowi nadaje przewodniczący rady powiatu, który zobowiązany jest do zwołania sesji, na co wskazuje art. 31 ust. 3 zdanie drugie u.s.p., a wcześniej do skierowania wniosku do komisji rewizyjnej w celu uzyskania opinii, o której mowa w tym przepisie. Jak podano w orzecznictwie, pojęcie zwołania sesji, użyte w art. 15 ust. 1 u.s.p., należy rozumieć jako należyte i wyczerpujące działania mające na celu przekazanie radnym informacji o miejscu, terminie i programie sesji. Bez wątpienia obowiązkiem przewodniczącego rady jest zawiadomienie wszystkich radnych o każdej sesji, nie ma tu znaczenia, czy jest to sesja zwołana przez przewodniczącego rady zgodnie z planem pracy, tzw. sesja zwyczajna, czy na wniosek zarządu lub grupy radnych stanowiących co najmniej 1/4 składu rady, tzw. sesja nadzwyczajna ${ }^{20}$. $\mathrm{Z}$ rozwiązania przyjętego $\mathrm{w}$ art. 15 ust. 1 u.s.p. wynika, że to przewodniczący rady powiatu zobowiązany jest podjąć czynności w przedmiocie zwołania rady powiatu w tym w przypadku, o którym mowa w art. 31 ust. 3 zdanie drugie u.s.p., ustawa nie przewiduje tu bowiem żadnego rozwiązania szczególnego, a zatem to on jest właściwy do przyjęcia wniosku o odwołanie starosty.

\footnotetext{
${ }^{20}$ Wyrok WSA w Szczecinie z 3 marca 2011 r., II SA/Sz 154/11, LEX nr 787498; wyrok WSA w Szczecinie z 3 marca 2011 r., II SA/Sz 155/11, LEX nr 1097088.
} 
Przewodniczący rady powiatu nie jest adresatem wniosku o odwołanie starosty, a jedynie podmiotem, do którego wniosek ten należy złożyć. Z ustawy nie wynika expressis verbis, że przewodniczący rady powiatu dokonuje kontroli formalnej złożonego wniosku, niemniej skoro określiła ona jego wymogi proceduralne, to jest oczywiste, że warunkiem nadania mu dalszego biegu jest sprawdzenie, czy zostały one spełnione. Wystąpienie braków formalnych powoduje, że wniosek nie może otrzymać biegu, przy czym ustawa nie przewiduje wzywania wnioskodawców do ich usunięcia. Po zwróceniu wniosku niespełniającego wymogów ustawowych można złożyć nowy wniosek, spełniający warunki, o których mowa w art. 31 ust. 1 i 2 u.s.p.

\section{PROBLEM COFNIĘCIA WNIOSKU LUB POPARCIA UDZIELONEGO WNIOSKOWI}

Ustawa nie przewiduje możliwości ani cofnięcia wniosku o odwołanie starosty, ani też wyraźnie nie dopuszcza możliwości cofnięcia przez poszczególnych radnych poparcia udzielonego wnioskowi. Jak wskazano w orzecznictwie, braku regulacji w zakresie możliwości cofania przez radnych oświadczeń woli (w tym przypadku wniosku o odwołanie starosty) nie można traktować jako luki prawnej, wydaje się on raczej wynikiem wielu uwarunkowań, w tym aksjologicznych, oraz potrzeby (której wyrazem są przepisy art. 31 u.s.p.) zapewnienia prawidłowego funkcjonowania organu kolegialnego - zarządu powiatu. Ustawodawca nie wypowiadając się w przedmiocie możliwości cofnięcia wniosku o odwołanie starosty uprzednio skutecznie złożonego przez grupę radnych, stanął na stanowisku, że z uwagi na skutki, jakie pociąga za sobą złożenie takiego wniosku, jego cofnięcie nie jest dopuszczalne, wymagane jest przeprowadzenie głosowania ${ }^{21}$. Stanowisko to należy w pełni podzielić, dodając, że ustawa o samorządzie powiatowym precyzyjnie określiła sekwencję czynności podejmowanych w następstwie złożenia wniosku o odwołanie starosty. Po sprawdzeniu wniosku od strony formalnej przewodniczący rady powiatu kieruje go do komisji rewizyjnej celem zaopiniowania, stosownie do wymogu wynikającego z art. 31 ust. 2 u.s.p. Głosowanie w sprawie odwołania rada powiatu przeprowadza po zapoznaniu się z opinią komisji rewizyjnej, przy czym ustawa określa w tym zakresie terminarz (art. 31 ust. 3 zdanie drugie u.s.p.). $Z$ art. 31 ust. 3 u.s.p. ani z żadnego innego przepisu tej

\footnotetext{
${ }^{21}$ Wyrok WSA w Gorzowie Wielkopolskim z 1 września 2016 r., II SA/Go 504/16, LEX nr 2104759.
} 
ustawy nie wynika, że przewidziano jakąkolwiek możliwość zatrzymania biegu postępowania w przedmiocie odwołania starosty, jak również zaniechania dalszych czynności w ramach tego postępowania. Ustawa określa, jakie czynności następują po sobie, przy czym są to czynności obligatoryjne (opinia komisji rewizyjnej, głosowanie), co jest następstwem złożenia wniosku o odwołanie starosty. Wniosek ten uruchamia procedurę w przedmiocie odwołania starosty, a skoro precyzyjnie określono, jakie następnie podejmowane są czynności (a więc uregulowano sekwencję czynności) i przesądzono, że muszą się one odbyć, to nie ma podstaw do przyjęcia, że możliwe jest cofnięcie wniosku czy też poparcie go ${ }^{22}$. Gdyby bowiem ustawodawca taką możliwość dopuścił, art. 31 u.s.p. miałby inne brzmienie, uzależniając głosowanie nad sprawą odwołania starosty od braku cofnięcia wniosku, a nie wyłącznie od jego zaopiniowania przez komisję rewizyjną.

Wniosek o odwołanie starosty ma z całą pewnością charakter publicznoprawny, za czym przemawiają ustawowe wymagania - określenie minimalnej liczby radnych, którzy mogą wystąpić z takim wnioskiem, wymóg pisemności i uzasadnienia, wymóg zaopiniowania przez komisję rewizyjną, zakaz przeprowadzania głosowania nad wnioskiem wcześniej niż po upływie miesiąca od jego złożenia ${ }^{23}$, wywołując w konsekwencji określone skutki w sferze prawa publicznego. Takim podstawowym skutkiem jest uruchomienie procedury w przedmiocie odwołania starosty, która mając charakter publicznoprawny, nie może być analizowana przez pryzmat przepisów prawa cywilnego, umożliwiających - choć w ściśle określonych przypadkach - cofnięcie złożonego oświadczenia woli. Inny jest bowiem charakter i cel przepisów prawa prywatnego. Odmienne stanowisko ${ }^{24}$ nie może być z powodów wskazanych powyżej podzielone. W konsekwencji przepisów tych nie można recypować na grunt ustawy o samorządzie powiatowym. To zaś wyklucza zarówno dopuszczenie możliwości cofnięcia wniosku o odwołanie starosty, jak również wycofania poparcia udzielonego wnioskowi przez poszczególnych radnych. Ich poparcie dla wniosku wymagane jest w dacie jego złożenia, zaś po nadaniu mu dalszego biegu wniosek - mając charakter publicznoprawny - jest faktem prawnym, z którym ustawa łączy określone skutki i nie mogą być one unicestwione późniejszą zmianą stanowiska radnych -

\footnotetext{
${ }^{22}$ Zob. A. KARCZMAREK, Opinia prawna dotycząca dopuszczalności odwolania poparcia dla sędziego kandydata do Krajowej Rady Sadownictwa, https://sejm.gov.pl/KRS/opinia2.pdf, s. 5-6.

${ }^{23}$ Wyrok NSA z 6 czerwca 2013 r., II OSK 992/13, LEX nr 1329160.

${ }^{24}$ Zob. m.in. wyrok WSA w Rzeszowie z 12 października 2006 r., II SA/Rz 702/06, https://orzeczenia.nsa.gov.pl/doc/49ADD213D7.
} 
wnioskodawców ${ }^{25}$. Nie są oni bowiem ani dysponentem wniosku - ustawa nie zna takiej konstrukcji, ani też nie mogą zniweczyć czynności, które wprost wynikają z ustawy, a są następstwem złożenia wniosku. Nie dysponują zatem prawem do cofnięcia poparcia udzielonego wnioskowi, bo byłaby to czynność sprzeczna z ustawą nie tylko dlatego, że nie jest ona znana ustawie i nie mieści się w jej zakresie przedmiotowym, ale dlatego, że pozostawałaby w ewidentnej sprzeczności z biegiem postępowania uregulowanego w art. 31 ust. 1-3 u.s.p. Nie ma przy tym znaczenia to, że ustawa o samorządzie powiatowym nie zawiera przepisu, który expressis verbis ustanawia nieskuteczność/bezskuteczność lub brak skutków prawnych wycofania poparcia. Takie rozwiązanie przewidziano w art. 9 ust. 3 ustawy z dnia 24 czerwca 1999 r. o wykonywaniu inicjatywy ustawodawczej przez obywateli ${ }^{26}$ (,Wycofanie poparcia udzielonego projektowi ustawy jest nieskuteczne"); art. 14 ust. 4 zdanie trzecie ustawy z dnia 15 września 2000 r. o referendum lokalnym ${ }^{27}$ (,Wycofanie udzielonego poparcia jest bezskuteczne") oraz art. $209 \S 1$ zdanie drugie, art. $303 \S 2 \mathrm{i}$ art. $427 \S 2$ zdanie drugie ustawy z dnia 5 stycznia $2011 \mathrm{r}$. - Kodeks wyborczy ${ }^{28}$ („Wycofanie udzielonego poparcia nie rodzi skutków prawnych" $)^{29}$. W analizowanym przypadku taki skutek - nieskuteczność wycofania poparcia udzielonego wnioskowi - stanowi następstwo przyjęcia w art. 31 ust. 1 u.s.p. zasady ostateczności udzielonego poparcia, której przejawem jest wyraźne określenie czynności podejmowanych w następstwie złożenia wniosku o odwołanie starosty, a tryb ten nie przewiduje - na żadnym etapie - ani badania, czy wniosek nadal popierany jest przez 1/4 ustawowego składu rady powiatu, ani też nie dopuszcza możliwości odmowy poddania wniosku pod głosowanie z powodu wycofania przez radnych udzielonego poparcia. Regulacja w tym zakresie jest zupełna, nie występuje tu żadna luka prawna, nie można zatem - w ramach wykładni prawa - poszukiwać podstawy prawnej uzasadniającej przyjęcie odmiennego stanowiska. Jak wskazano, śmierć starosty w trakcie postępowania w przedmiocie jego odwołania jest okolicznością, która bezprzedmiotowym czyni głosowanie w sprawie jego odwołania, albowiem na skutek śmierci mandat starosty wygasł. Jak

\footnotetext{
${ }^{25}$ Rozstrzygnięcie nadzorcze Wojewody Lubuskiego Nr NK-I.4131.136.2016.TDom z dnia 22 kwietnia 2016.

${ }^{26}$ Tekst jedn. Dz.U. z 2018 r., poz. 2120.

${ }^{27}$ Tekst jedn. Dz.U. z 2019 r., poz. 741.

28 Tekst jedn. Dz.U. z 2020 r., poz. 1319.

${ }^{29}$ Zob. M. DOBROwOLSKI, Opinia prawna dotycząca dopuszczalności ewentualnie braku dopuszczalności wycofania poparcia dla sędziego - kandydata zgłoszonego do Krajowej Rady Sądownictwa przez grupę co najmniej 25 sędziów albo grupę co najmniej 2000 obywateli (art. 11 a ust. 2 ustawy o KRS), https://sejm.gov.p1/KRS/opinia2.pdf, s. 2.
} 
trafnie wskazano w orzecznictwie, śmierć pracownika jest zdarzeniem, które prowadzi do wygaśnięcia stosunku pracy ${ }^{30}$. W takim przypadku nie ma żadnego uzasadnienia i podstawy prawnej do przeprowadzenia czynności, o których mowa w art. 31 ust. 3 u.s.p. Żadna inna okoliczność nie uzasadnia odstąpienia od tych czynności.

\section{PODSUMOWANIE}

Przeprowadzone rozważania pozwalają na sformułowanie następujących wniosków: odwołanie starosty jest instytucją prawa publicznego uregulowaną w ustawie o samorządzie powiatowym. Skuteczne złożenie wniosku obliguje do nadania mu dalszego biegu, zaś ustawa określa dalsze etapy postępowania $\mathrm{w}$ przedmiocie odwołania starosty (opinia komisji rewizyjnej, głosowanie). Spełnienie wymogów formalnych, o których mowa w art. 31 ust. 1 i 2 u.s.p., ocenia się na dzień (w dacie) złożenia wniosku, a późniejsze wycofanie wniosku czy też poparcia udzielonego wnioskowi nie jest dopuszczalne. Takie oświadczenie nie rodzi żadnych skutków prawnych i nie powoduje, że przeprowadzenie głosowania, zgodnie $\mathrm{z}$ art. 31 ust. 3 u.s.p., nie jest możliwe. Ustawa nie określa precyzyjnie, jakie przyczyny uzasadniają złożenie wniosku o odwołanie starosty i finalnie jego odwołanie, zastrzegając jedynie, że nie mogą to być te przyczyny, które uzasadniają nieudzielenie absolutorium lub nieudzielenie wotum zaufania zarządowi powiatu. Nie ma zatem żadnych przeszkód, aby przez ,inną przyczynę” w rozumieniu art. 31 ust. 1 u.s.p. rozumieć każdą inną okoliczność, która odnosi się do osoby starosty lub jego działalności.

\section{BIBLIOGRAFIA}

ŹRÓDŁA PRAWA

Ustawa z dnia 5 czerwca 1998 r. o samorządzie powiatowym, tekst jedn. Dz.U. z 2020 r., poz. 920.

Ustawa z dnia 24 czerwca 1999 r. o wykonywaniu inicjatywy ustawodawczej przez obywateli, tekst jedn. Dz.U. z 2018 r., poz. 2120.

Ustawa z dnia 15 września 2000 r. o referendum lokalnym, tekst jedn. Dz.U. z 2019 r., poz. 741.

Ustawa z dnia 5 stycznia 2011 r. - Kodeks wyborczy, tekst jedn. Dz.U. z 2020 r., poz. 1319.

Ustawa z dnia 11 stycznia 2018 r. ustawy o zmianie niektórych ustaw w celu zwiększenia udziału obywateli w procesie wybierania, funkcjonowania i kontrolowania niektórych organów publicznych, Dz.U. z 2018 r., poz. 130.

\footnotetext{
${ }^{30}$ Wyrok SN z 8 czerwca 2001 r., I PKN 466/00, LEX nr 1212622.
} 


\section{ORZECZNICTWO}

Wyrok NSA z 22 marca 1996 r., SA/Gd 3695/95, LEX nr 79742.

Wyrok SN z 8 czerwca 2001 r., I PKN 466/00, LEX nr 1212622.

Wyrok NSA z 14 stycznia 2002 r., I SA/Po 1606/01, „Finanse Komunalne” 2003, nr 2, s. 56.

Wyrok WSA w Rzeszowie z 12 października 2006 r., II SA/Rz 702/06, https://orzeczenia.nsa.gov.pl/ doc/49ADD213D7.

Wyrok WSA w Szczecinie z 3 marca 2011 r., II SA/Sz 154/11, LEX nr 787498.

Wyrok WSA w Szczecinie z 3 marca 2011 r., II SA/Sz 155/11, LEX nr 1097088.

Wyrok NSA z 6 czerwca 2013 r., II OSK 992/13, LEX nr 1329160.

Wyrok WSA we Wrocławiu z 30 marca 2016 r., III SA/Wr 86/16, LEX nr 2063628.

Wyrok WSA we Wrocławiu z 30 marca 2016 r., III SA/Wr 84/16, LEX nr 2063625.

Wyrok WSA z 30 marca 2016 r., III SA/Wr 82/16, LEX nr 2063620.

Wyrok WSA w Szczecinie z 12 maja 2016 r., II SA/Sz 249/16, LEX nr 2098486.

Wyrok WSA w Gorzowie Wielkopolskim z 1 września 2016 r., II SA/Go 504/16, LEX nr 2104759.

Wyrok SO w Gorzowie Wielkopolskim z 22 czerwca 2017 r., VI Pa 35/17, LEX nr 2659619.

Postanowienie WSA w Gliwicach z 10 sierpnia 2017 r., IV Sa/G1 711/17, LEX nr 2345257.

Wyrok WSA w Gliwicach z 8 listopada 2017 r., IV SA/G1 280/17, LEX nr 2396880.

Wyrok WSA w Warszawie z 14 listopada 2016 r., II SA/Wa 2177/05, LEX nr 295001.

Wyrok WSA w Rzeszowie z 20 grudnia 2017 r., II SA/Rz 1034/17, LEX nr 2434076.

Wyrok WSA w Rzeszowie z 20 grudnia 2017 r., II SA/Rz 1033/17, LEX nr 2434075.

\section{ORZECZNICTWO ADMINISTRACYJNE}

Uchwała Kolegium Regionalnej Izby Obrachunkowej z 24 lipca 2013 r., 79/2013, LEX nr 1728402.

Rozstrzygnięcie nadzorcze Wojewody Lubuskiego Nr NK-I.4131.136.2016.TDom z dnia 22 kwietnia $2016 \mathrm{r}$.

\section{LITERATURA}

DOBROWOLSKI Marek: Opinia prawna dotycząca dopuszczalności ewentualnie braku dopuszczalności wycofania poparcia dla sędziego - kandydata zgłoszonego do Krajowej Rady Sądownictwa przez grupę co najmniej 25 sędziów albo grupę co najmniej 2000 obywateli (art. 11a ust. 2 ustawy o KRS), https://sejm.gov.pl/KRS/opinial.pdf, s. 1-5.

KARCIARZ Mateusz: Raport o stanie jst - istota, zakres, przygotowanie, LEX/el 2018.

KARCZMAREK Adam: Opinia prawna dotycząca dopuszczalności odwołania poparcia dla sędziego kandydata do Krajowej Rady Sądownictwa, https://sejm.gov.pl/KRS/opinia2.pdf, s. 1-7.

Komentarz do ustawy o samorządzie powiatowym, red. Paweł Chmielnicki, Warszawa: LexisNexis 2005, komentarz do art. 31.

Ustawa o samorządzie powiatowym. Komentarz, red. Bogdan Dolnicki, Warszawa: Dom Wydawniczy ABC 2007, komentarz do art. 31. 


\title{
WNIOSEK O ODWOEANIE STAROSTY \\ W ŚWIETLE USTAWY Z DNIA 5 CZERWCA 1998 R. O SAMORZĄDZIE POWIATOWYM
}

\author{
Streszczenie
}

Artykuł dotyczy problematyki odwołania starosty z pełnionej funkcji w świetle ustawy z dnia 5 czerwca 1998 r. samorządzie powiatowym. Zdaniem autorki wniosek o odwołanie starosty, o którym mowa w art. 31 ust. 1 wskazanej ustawy, jest oświadczeniem o charakterze postulatywnym, które zobowiązuje radę powiatu do jego rozpoznania. Złożenie wniosku o odwołanie starosty wszczyna postępowanie w przedmiocie odwołania starosty, którego kolejne etapy zostały wyraźnie określone $\mathrm{w}$ ustawie. Jego finałem jest podjęcie uchwały w przedmiocie wniosku, przy czym $\mathrm{z}$ ustawy o samorządzie powiatowym wynika, że warunkiem odwołania starosty jest uzyskanie większości co najmniej 3/5 ustawowego składu rady. Ustawodawca nie przewidział ani możliwości cofnięcia wniosku o odwołanie starosty, ani też nie uregulował możliwości wycofania przez radnych poparcia udzielonego takiemu wnioskowi. Samo złożenie wniosku wywołuje określone skutki o charakterze publicznoprawnym, a ustawa wyraźnie określa sekwencję czynności podejmowanych w następstwie złożenia wniosku. W tym zakresie nie przewidziano możliwości umorzenia postępowania ze względu na cofnięcie wniosku lub wycofanie poparcia przez radnych dla wniosku. W konsekwencji złożony wniosek o odwołanie starosty musi prowadzić do głosowania w sprawie odwołania, zaś radni, którzy poparli wniosek, a następnie odmawiają jego poparcia, mogą to uczynić podczas głosowania w sprawie odwołania.

Słowa kluczowe: starosta; odwołanie starosty

APPLICATION FOR DISMISSAL OF A STAROSTA

IN THE LIGHT OF THE ACT OF 5 JUNE 1998. ON POVIAT SELF-GOVERNMENT

S u m mary

The article concerns the issue of dismissal of a starost from his function in the light of the Act of June 5, 1998 of the poviat self-government. According to the author, the request to dismiss the starost referred to in art. 31 section 1 of the said Act is a postulative statement which obliges the poviat council to recognize it. The submission of an application for dismissal of the starost initiates the proceedings regarding the dismissal of the starost, whose subsequent stages have been clearly defined in the Act. Its finale is the adoption of a resolution on the application, whereby the Act on poviat selfgovernment shows that the condition for dismissal of a starost is obtaining a majority of at least $3 / 5$ of the statutory composition of the council. The legislator did not provide for the possibility of withdrawing the application for dismissal of the starost, nor did it regulate the possibility for the councilors to withdraw their support for the application. The submission of the application itself has certain publiclaw effects, and the Act clearly defines the sequence of actions taken following the submission of the application. In this respect, there is no possibility of discontinuing the proceedings due to withdrawal of the application or withdrawal of support by the councilors for the application. Consequently, the application for dismissal of the starost must lead to voting on the appeal, and councilors who supported the request and then refuse to support it may do so when voting on the appeal.

Keywords: starost; dismissal of the starost 